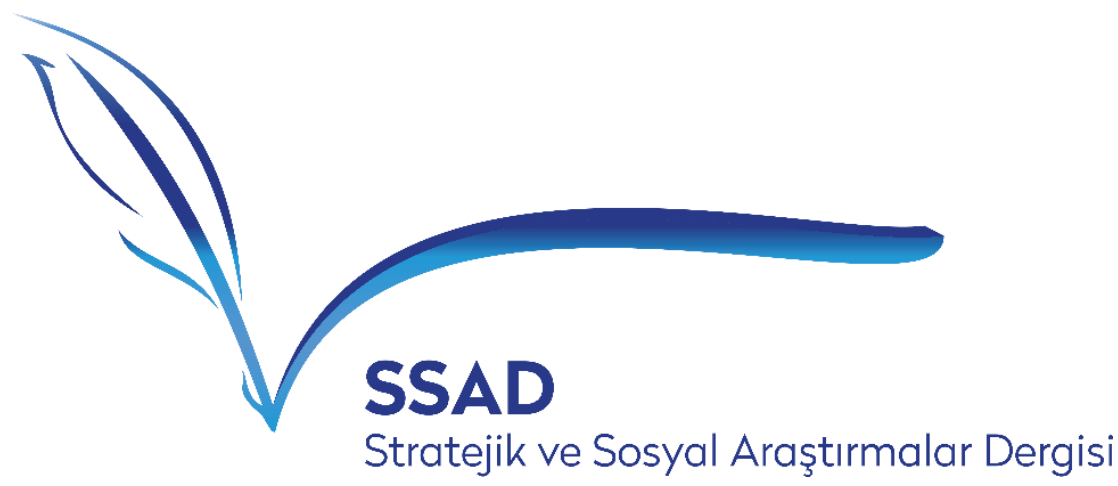

ISSN: $2587-2621$

Volume 3 Issue 1, March 2019

Makale Gönderim Tarihi: 28.11.2018 Makale

Kabul Tarihi: 02.03.2019

\title{
EFLAK- BOĞDAN- ERDEL VOYVODALARI VE OSMANLI İSTIHHBARATINA DAİR ROLLERİ
}

\author{
The Voivodes of Wallachia Moldavia Transylvania and Their Roles About of \\ Ottoman Intelligence
}

\author{
Dr. Mevlüde Gökçen DAŞ DARICI \\ Sivas Cumhuriyet Üniversitesi, Sosyal Bilimler Enstitüsü, Tarih Anabilim Dalı \\ gokcen.das@gmail.com \\ Orcid: 0000-0002-5592-5495
}

Öz: 14. yüzyıl sonlarından itibaren Eflak'1, 15. yüzyıl başlarından itibaren Boğdan'1 ve 16. yüzyıldan itibaren Erdel'i hâkimiyeti altına alan Osmanlı idaresi, bu tarihe kadar bölgede hüküm süren beyleri de itaat altına alıyor, böylelikle o havalideki beyler eski statülerini koruyarak Osmanlı'ya haraç ödeyen imtiyazlı beyler statüsü kazanıyorlardı. Voyvoda adı verilen ve yerli aristokrat aileler arasından seçilen bu beylerin siyasi, toplumsal ve dini yapısını muhafaza etmesine izin veren Osmanlı idaresi onlardan; askeri, ekonomik ve siyasi açıdan istifade ediyordu. Balkanlarda henüz tam bir hâkimiyet kurulmamışken bölge panoramasını anlamak ve anlamlandırmak adına sağlamış oldukları istihbarî bilgi akışı ise onları dış politikada aktif bir pozisyona çıkarıyordu. Dost ve müttefik bir vasal konumunda olan bu siyasi teşekküllerin temsilcisi olan voyvodaların Osmanlı idaresine olumlu katkıları yahut olumsuz birtakım etkileri olmuştur. Deyim yerindeyse Osmanlı'nın Avrupa ve Balkanlardaki gözü kulağı olan voyvodaların bazen bu istihbarî vazifelerini aksattığı hatta kötüye kullandığı görülmüştür. Konuya dair menfi misallerden biri olan Yuvan'ın isyan hadisesi esnasında Osmanlı arşivine yansıyan bazı kayıtlar 16. yüzyıl Osmanlı istihbarat faaliyetleri hakkında mühim ipuçları içermektedir.

Çalışma temel olarak Başbakanlık Osmanlı Arşivinden temin edilen 3, 5, 6, 7, 12, 14/1, 16, 21, 24, 25, 26, 27, 32, 43, 64, 72, 82 numaralı Mühimme Defterlerindeki ilgili evraka dayanılarak hazırlanmıştır. Ayrıca konuya ilişkin araştırmainceleme eserlerden de istifade edilmiştir.

Anahtar Kelimeler: Osmanlı İmparatorluğu, İstihbarat, Voyvoda, İsyan, Eflak-Boğdan- Erdel, Casus.

Abstract: Since the end of the 14th century Wallachia, 15th at the beginning of the century, Moldavia and 16th century Transylvania's area under Ottoman administration until this date, the ruling rulers in the region also obeyed, so that the gentlemen earned the status of privileged gentlemen paying tribute to the Ottoman Empire. The Ottoman administration, 
which allows these gentlemen, who are chosen as Voivode from among the indigenous aristocratic families, to preserve their political, social and religious structure; military, economic and political benefits. While the Balkans was not yet fully established, the intelligence information flow they provided in order to understand and make sense of the panorama of the region had taken them to an active position in foreign policy. Voivodes, the representative of these political organizations, which are in the position of a friendly and allied vassal, had positive contributions or negative effects to the Ottoman administration. The Voivodes, which were the eyes of the Ottoman Empire in Europe and the Balkans, were sometimes disrupted or even misused by these intelligence missions. Some of the records reflected in the Ottoman archives during the rebellion of Yuvan, one of the negative.

The study is mainly related to the relevant documents in Mühimme Books numbered 3, 5, 6, 7, 12, 14/1, 16, 21, 24, 25, 26, 27, 32, 43, 64, 72, 82 obtained from the Ottoman Archive of the Prime Ministry based on. In addition, the research and analysis of the subject has been used.

Keywords: Ottoman Empire, Intelligence, Voivodeship, Rebellion, Wallachia, Moldavia, Transylvania, Spy.

\section{Giriş}

Voyvoda; Eflak, Boğdan ve Erdel beyleri için kullanılan unvan olup, Slavca "asker" anlamındaki 'voy' ile (voyska) "sürmek" anlamındaki 'voda'dan (vodity) meydana gelerek; "asker sürücü" anlamını kazanmıştır. Buradan hareketle kelime "bir memleketin başkumandanı ve idarecisi" manasına gelmektedir (Maxim, 2013, s. 128). Osmanlı idaresi 1391 yılında Eflak'1, 1456 yılında Boğdan'1, son olarak 1541'de Erdel'i kontrolü altına alarak vergiye bağlamış fakat bu prensliklerin yerel kurumlarına müdahale etmemiştir. Voyvodalıkların din adamları ve yerli boyarlar tarafından seçilen diğer vazifeliler, Osmanlı idaresi tarafından onaylandıktan sonra görevlerine başlamıştır. Dolayısıyla bu prensliklerin, kendi içlerinde nispeten serbest bir yönetim uygulamalarına izin verilmiştir. Osmanlı merkez idaresi ayrıca, bu siyasi birliklerin kendi topraklarında uygulamış oldukları yönetime karışmamış, bölgede bir iskân politikası gütmemiş, Müslümanlaştırılmaya çalışmamış, Türklerin bu bölgelerden toprak almalarına, mescit ve cami yapmalarına izin vermemiştir (Papp 2002, s. 745; Sözen 2002, s. 16 ). Buna karş1lık onlara, temel bazı mükellefiyetler yüklenmiş, böylece üzerlerinde denetimli bir serbestlik oluşturulan prensliklerin, Osmanlı idaresine bağl1 dost ve müttefik bir vasal haline getirilmesi amaçlanmıştır.

Başlangıçtan beri en önemli vazifeleri; haraçlarını zamanında ödemek, imparatorluğun dış politikasına uymak, sultanın seferlerine katılmak ve Osmanlı idaresinin menfaatleri ile çatışan komşu devletlerin hareketleri hakkında bilgi toplamak (Panaite, Ankara 1999, s.376-377; Kantemir, Ankara 1979, s. 286) olan voyvodalar, istihbarî faaliyetlerde oldukça etkin bir şekilde yer almışlardı (Çiftçi, 2010, s. 28). İmparatorluk merkezinden oldukça uzak bir bölgede görev almalarına rağmen onların bu etkinlikleri oldukça özgün özellikler taşımaktaydı. Voyvodalar aracılığıyla yürütülen bilgi toplama faaliyetleri, belirli bir süreklilik ve düzen arz etmesinin yanında Osmanlı istihbaratının en sistematik ve kapsamlı çalışmaları olma niteliğine sahiptir (Yüksel 2013, s. 134). Voyvodaların; Viyana, Varşova, Kiev ve Petersburg gibi Osmanlıları daha yakından ilgilendiren kentlerde Avrupa'daki siyasî geliş̧melere dair edindikleri bilgileri kendilerine aktaran bir veya daha fazla sayıda ajan ve havadisnüvisleri bulunuyordu. (Yüksel 2014, s. 82). Havadisnüvislerin mevcut olmadığı veyahut geç ya da yetersiz kaldıkları zamanlarda casuslar tedarik ederlerdi. Edindikleri istihbaratı ise bir "menzil-i mahsus" ile Osmanlı başkentine ulaştırırlardı. Edinilen istihbaratı değerlendirir, söz konusu malumat kesin ve sahih olmaktan uzaksa İstanbul'dan kendilerine en doğru istihbarata ulaşmak için biraz daha süre tanınmasını isteyebilir, doğrulanmalarının zamana bağlı olduğunu belirterek olası gecikmenin de kendi kusur veya rehavetlerinden kaynaklanan bir gelişme olarak değerlendirilmemesi gerektiğini haber verirlerdi (Yüksel 2013, s. 135).

Bölge coğrafyasında herhangi askeri hareketlilik söz konusu olduğunda destekleri beklenen voyvodaların bu hizmetleri istihbarî bir amaca yönelik olmanın yanında maddi bir yardımı da ihtiva ediyordu. Mesela Kili ve Akkirman kalelerinin alınmasında (1484) Eflak voyvodasının; 
Hadım Ali Paşa'nın 1485'de Boğdan üzerine gerçekleştirdiği seferde, Eflak ve Boğdan voyvodalarının istihbarî, askerî ve malî yararlılıkları görülmüştü (Müneccimbaş1, 1974, s.381383). Peçevî'ye göre öteden beri Eflak voyvodaları, Padişah seferlerinde savaş ihtiyacı olarak top arabaları için beygir veregelmişlerdir. Söz gelimi III. Murad Wesprim Seferine çıkarken Eflak voyvodası 400 baş beygir ve haracını göndermişti (Peçevi, 1982, s.140). Sultan ayrıca 1579'da çıkılacak olan Şark Seferi için Boğdan ve Eflak voyvodalarından zahire ve haraç temin etmişti.

Bu haraç 10 bin kese arpa, 10 bin kese un, yeteri kadar çok bal ve yağı (vafir-i müstevfa) içeriyordu (BOA, A. DVNSMHM d.32, s.287, hüküm: 523, 524, 27 Zilkade 986/ 25 Ocak 1579 ).

\section{Voyvodaların İstihbarattaki Rolleri}

Voyvodaların istihbarat içerisinde faal birer aktör gibi gözükmelerinin nedenlerinden en önemlisi bölge coğrafyasındaki gelişmeleri yakından takip ederek merkezi idareye bildirmelerinin yanında bilhassa bu husus için casuslar vazifelendirmeleridir. Voyvodaların vazifelendirdiği casuslar bölge coğrafyasında, Osmanlı idaresini tehdit edebilecek her türlü askeri, siyasi veya sosyal gelişmeyi yakından takip ediyor, toplanan bilgiler voyvoda kanalıyla İstanbul'a bir rapor halinde sunuluyordu. Merkezi idare bu yolla edinilen istihbaratı değerlendiriyor, gerekli görürse başka bilgi kanallarıyla besleyerek istihbaratın doğrulamasını yapıyordu. Mesela Boğdan voyvodas1; Rusların Lehistan'dan kendilerine kattıkları topraklarda 110 bin askerlerinin ve Karadeniz'deki bazı tersanelerde 124 adet gemilerinin bulunduğunu haber vermiş, ayrıca Varşova'daki bir İsveç elçisinin mektubunu ele geçirip İstanbul'a göndermişti. Ancak voyvodadan gelen raporlar, Osmanlı yöneticilerinin merak ve endişelerini gidermeye yetmeyince diğer bilgi kanallarını ${ }^{1}$ devreye sokmuşlardı (Yüksel, 2014, s. 93). Görüldüğü üzere voyvodalar ve diğer bilgi kanallarının sağladığı bilgi akışı sayesinde gerekli stratejiyi oluşturmak ve mevcut duruma uygun pozisyon almak kolaylaşıyordu. Nitekim Boğdan voyvodalarından olan Aleksandr'ın da bölge coğrafyasında Osmanlı idaresi açısından bir tehdit unsuru olan Lehliler, Tatarlar ve Ruslarla ilgili detaylı incelemeler yaptığı ve bu faaliyetler neticesinde elde etmiş olduğu ayrıntılı malumatı, Osmanlı merkez idaresiyle paylaşmak konusunda yararlılık gösterdiği anlaşılıyor. Voyvoda Aleksandr, Lehistan Kralı'nın himayesindeki bazı vazifelilerin Kral aleyhine birtakım uygunsuzluklarını tespit edip İstanbul'a bildirmişti. Aleksandr ayrıca, memlekette fesat ve eşkıyalık çıkarmak gibi suçlara bulaşan bu kişilerin Boğdan sınırındaki halka zarar verdiği konusunda bilgilendirdiği Osmanlı merkezi idaresinden, söz konusu eşkıya birliklerinin verdiği zararı tazmin etmek ve onlardan intikam almak için icazet istemişti (BOA, $A$. DVNSMHM d. 3, s. 37, hüküm: 93, 7 Şevval 966/ 13 Temmuz 1559). Koyun taciri görünümündeki bazı kimselerin şüpheli davranışları da voyvodanın dikkatinden kaçmamış, İstanbul'a arz edilen bu durum üzerine, söz konusu kimselerin tutuklanarak merkeze gönderilmesi istenmişti (BOA, $A$. DVNSMHM d. 3, s. 37, hüküm: 92, 28 Ramazan 966/ 4 Temmuz 1559). Böylece ticaret bahanesiyle ülke içerisinde dolaşan yabancıların oluşturabileceği tehdide karşı önlemler alınmış, bu konuda voyvodaların istihbarî bilgi ve birikiminden istifade edilmişti. Voyvodaların istihbarat elde etmek için istifade ettiği kanallardan biri tacir görünümlü casusları olmuştur. Söz konusu bilgi kanalı özellikle, istihbarat toplama çalışmaları sekteye uğradığında verimli bir şekilde kullanılagelmiştir (Yüksel, 2014, s.82,83,93).

Boğdan voyvodalarından Petre'nin casusları aracılığıyla edindiği ve Osmanlı karasularında tehdit oluşturabilecek bir askeri birliğin toplanmakta olup, karaya çıkmak niyetinde olduklarını

\footnotetext{
${ }^{1}$ Diğer bilgi kanallarıyla ilgili daha ayrıntılı malumat için bkz. Ahmet Yüksel, II. Mahmud Devrinde Osmanlı İstihbaratı, Kitap Yay., İstanbul 2013, s. 108-176; A.Yüksel, Rusların Kafkasya’yı İstilası ve Osmanlı İstihbarat Ağı, Dergâh Yay., İstanbul 2014, s. 84-93.
} 
havi istihbarat (BOA, A. DVNSMHM d. 64, s.155, hüküm: 401, 26 Zilkade 996/ 17 Ekim 1588) ${ }^{2}$ merkezi idareye ulaşınca, Osmanlı idaresi; Tırhala Beyi'ne ve Bender Muhafizı Serdar Bey'e, ahvali tecessüs etmek için casuslar gönderilmesini toplanan askeri birliklerin niyetleri anlaşıldıktan sonra ne gerekiyorsa yapılmasını emretmiş̧ti.

Merkezi idare ile voyvodalar arasındaki yazışmalarda mükerrer şekilde daima o taraftan yarar casusların eksik etmeyesin, her ne duyum almışsan bildirmekten hali olmayasın şeklindeki tembihlere sıklıkla rastlanıyor oluşu onların istihbarî rollerinin altını çiziyor (BOA, A. DVNSMHM d... 3, s. 43, hüküm: 112, 10 Şevval 966/ 16 Temmuz 1559; BOA, A. DVNSMHM d... 3, s. 37, hüküm: 93, 7 Şevval 966/ 13 Temmuz 1559; BOA, A. DVNSMHM d... 27, s. 215, hüküm: 492, 20 Şevval 983/ 12 Ocak 1576; BOA, A. DVNSMHM d...64, s.96 hüküm: 299, 21 Safer 992/ 4 Mart 1584). Büyük bir gizlilik içerisinde yürütmeleri gereken istihbarat çalışmaları sırasında sadakat içinde olmaları, rehavet ve gaflete kapılmamaları, sözüne güvenilir ve anlayışı bol casuslara çeşitli ikramlarda bulunarak iyi muamele etmeleri, masrafa (Yüksel, 2017, s. 615) ve toplanan bilginin önemine bakmaksızın çalışmalarına devam etmeleri (Yüksel 2013, s.134.) de İstanbul'dan kendilerine en sık yapılan hatırlatmalardı.

Merkezden istihbarî vazife ile gönderilen memur veya askerîlerin işlerini kolaylaştırmak adına, voyvodalardan kılavuz talep edilmesi ortak bir istihbarî amaca hizmet ediyor olmalıdır. Nitekim Osmanlı ülkesinden bir vazife gereği çıkış yapan memur veya askerîlerin karşılaştıkları ilk sorun yabancı dil bilmemeleri ve gittikleri coğrafyaya vakıf olmamalarıydı. Bu durumda ihtiyaç duyulan; güvenilir, anlayışlı, her iki dile de vakıf, bölge coğrafyasını iyi tanıyan tercüman ve kılavuzların temin edilmesi noktasında voyvodalara büyük bir iş düşüyordu. Nitekim Boğdan voyvodasından mühim ve acil bir iş için Lehistan'a giden Ahmet Çavuş'a bir yarar bir kılavuz vermesi ayrıca Lehistan ahvalini tecessüs için bir casus vazifelendirmesi istenmişti (BOA, A. DVNSMHM d. 21, s.178, hüküm: 429, 14 Zilkade 980/18 Mart 1573). Ayrıca Erdel ve Macaristan tarafından edindiği haberleri Osmanlı merkezine bildiren Boğdan voyvodasının bu hizmeti oldukça takdir toplamış, vazifesine devam etmesi ve güvenilir adamları aracılığıyla edindiği haberleri vakit kaybetmeksizin merkeze bildirmeye devam etmesi hususunun altı çizilmişti ( $B O A$, A. DVNSMHM d. 14/1, s.434, hüküm: 616, 22 Cemaziyelevvel 978/22 Ekim 1570).

İstihbarat faaliyetlerinde aktif rol oynadıklarına dair bir diğer güçlü kanıt askeri harekâtlar öncesi ve esnasında sergilemiş oldukları görüntüdür. Nitekim bölge coğrafyasına olan hâkimiyetleri, çıkılacak seferlerin askeri hazırlık safhasında ihtiyaç duyulan istihbarî bilgiyi elde etmeyi kolaylaştırıyordu. Mesela Malkoçoğlu Bali Bey Lehistan üzerine keşif akını için gönderildiğinde, Bali Bey’e kllavuzluk etmesi için Boğdan voyvodası vazifelendirilmişti (Müneccimbaşı, s.401). Sadece Osmanlı tarafının düzenlediği seferlerdeki istihbarî süreçte değil, düşman hazırlık ve akınlarının önceden haber alınmasında da ciddi katkı ve yararlılıkları görülmüştür. Nitekim 1559'da Azak ve Cankirman kaleleri üzerine; Çar IV. İvan'ın önemli komutanlarından olan Dimitriy Vinevetskiy (Dimitraş) önderliğinde müttefik bir kuvvetle hareket edileceğinin haberini merkeze ileten Boğdan voyvodasıydı (BOA, A. DVNSMHM d... 3, s.41, hüküm: 102, 7 Şevval 966/ 13 Temmuz 1559). Osmanlı merkez idaresi bu yolla Rusya ve Avusturya arasındaki ittifakı haber alınca Eflak ve Boğdan voyvodalarına Ferdinand'ın (Ferenduş Kral) aralarındaki ahitnameye aykırı olarak asker toplayıp toplamadığı, Erdel- Eflak ve Boğdan'da ahvalin ne durumda olduğu, toplanan cemiyetin eşkıya cemiyeti mi yoksa Ferdinand'ın askeri mi olduğunun iyice araştırılıp bildirilmesini istemişti (BOA, A. DVNSMHM d... 3, s.68, hüküm:178, 179,180, 27 Şevval 966/ 2 Ağustos 1559). 1559-1563 arasında Adaşev' in

\footnotetext{
${ }^{2}$ Boğdan Voyvodası Petre'den mektup gelip, kâfir cemiyet üzeredir karaya çımak niyetindedir derler ne canibe hareket edeceğini bilmeziz ĕger üzerimize gelirler ise biz de varırı deyu haber verip badehu düşman ahvalini tecessüs için casuslar gönderip niyetleri anlaşıldıktan sonra icabının icrası. (Evrakta mühimdir ibaresi bulunuyor, haberi İstanbul'a göndermek için Rumeli çavuşlarından Mehmed Çavuş vazifelendirilmiştir).
} 
Özi, Vinevetskiy'nin Azak-Taman arasında gerçekleştirdiği saldırıları kapsayan Eflak- Boğdan olayları esnasında yine Eflak ve Boğdan voyvodalarının askeri ve istihbarî hizmetleri görülmüştür (Öztürk, 2005, s.63).

1576'da Boğdan Voyvodasının Avusturya'daki casusları, Avusturya askerlerinin toplanmakta olduğunu müşahede edip bu haber Boğdan voyvodası tarafından merkezi idareye bildirilince hem voyvoda merkezi idarenin taltifine mazhar olmuş hem de savaş ihtimaline karş1 gerekli tedbirlerin alınması için zaman kazanılmıştı (BOA, A. DVNSMHM d.5, s.689, hüküm: 747, 9 Cemaziyelahir 973/ 1 Ocak 1576). Aynı yıl Lehistan kralı ölünce bölgedeki kargaşa ihtimali kendini belli etmişti. Bu noktada Erdel voyvodasına; çıkan karmaşa ortamından ötürü Rusya tarafından Lehistan'a yapılabilecek bir teyakkuza karşı hazırlıklı olması, Avusturya tarafından Erdel'e tecavüz olması durumunda Budin ve Timeşvar askeri ile karşılık vermesi emredilmişti.

Ayrıca, daima o havalideki casuslarını eksik etmemesi, her türlü tehlikeye karşı hazırlıklı olmak için gerekli tedbirleri alması yönünde uyarı ve tembihler de unutulmamıştı (BOA, A. DVNSMHM d... 27, s. 215, hüküm: 492, 20 Şevval 983/12 Ocak 1576).

Osmanl1-Avusturya ve Osmanlı-Macar münasebetlerinin perde arkasına bakıldığında yine bizzat voyvodalar veya onların görevlendirdiği casuslar aracılığıyla siyasi ve askeri panoramanın yakından takip edildiği görülüyor. Mesela Avusturya kralının memlekette geniş çaplı bir ücretli asker yazımı yaptırdığının casuslar vasıtasıyla haber alınması, üstelik haraç verme işini de ertelemesi, merkezi idareyi Avusturya'nın Osmanlı üzerine bir sefer niyetinde olabileceği konusunda şüpheye düşürmüş̧ü. Bunun üzerine Budin Beylerbeyine; yarar casuslar göndererek o tarafa göz kulak olunmasl, ahvalin tahkik olunarak merkeze bildirilmesi emredilmişti (BOA, A. DVNSMHM d.16, s. 268, hüküm: 523, 23 Zilkade 979/7 Nisan 1572).

Görüldüğü üzere askeri karşılaşmaların hem psikolojik ve lojistik hazırlık aşamasında, hem de seferler esnasında voyvodaların yardım ve desteği alınmıştı. Tehdit Osmanlı idaresine yönelik olsun ya da olmasın, bölge coğrafyasında hüküm süren diğer siyasi birliklerin askeri yahut politik tutum ve niyetlerinin öğrenilmesine yönelik sürdürmüş oldukları istihbarî hizmet, Osmanlı merkez idaresinin dış politikasını şekillendirmesinde önemli bir etmendi. Söz gelimi Eflak ve Boğdan voyvodalarının İstanbul'a sundukları raporlarda; Rusya ile İsveç arasındaki anlaşmazlığın bertaraf olunduğu, Napolyon savaşları ve Rusların savaş içerisindeki durumunu Rus İmparatoru'nun Prusya ve Danimarka krallarıyla olan sürtüşmelerini ayrıntılarıyla aktarmaktan geri durmamışlardı (Yüksel, 2014, s.84).

Voyvodalardan; isyan, eşkıyalık, reayaya karşı haksız uygulamalar gibi iç istihbaratı kapsayan meselelerin tespiti ve önlenmesi noktasında da istifade ediliyordu. Mesela 1559 'da Erdel'de toplanarak, Eflak voyvodası Mirço'ya karşı ayaklanmaya girişecek bir ehl-i fesat birliğinin varlığından Boğdan voyvodası marifetiyle bilgilendirilen Osmanlı idaresi, ondan söz konusu durumla ilgili olarak hem istihbarî hem askerî açıdan yardım ve destek almıştı (BOA, $A$. DVNSMHM d... 3, s.237, 241, hüküm: 373, 383, 29 Zilhicce 966/ 2 Ekim 1559 ). 1564 'te Kili ve Akkirman'a ticaret maksadıyla giriş yapan bazı Boğdanlıların Akkirman'da saldırıya uğradıkları bazılarının yaralandığı bazılarının da öldürüldüğü bilgisi Boğdan voyvodası tarafından merkezi idareye bildirilince, Kili ve Akkirman Beyleri merkezi idarenin tedibinden nasibini almıştı (BOA, A. DVNSMHM d.6, s., hüküm: 75, 26 Muharrem 972/ 3 Eylül 1564). Akkirman beyi Hasan Bey, Boğdan reayasına haberler göndererek; Nehr-i turla (Dinyester nehri) buz tutunca, buradan Tatar askerini gönderip Boğdan vilayetini alacağı, ayrıca Dobruca'yı da zapt edeceği tehdidinde bulunmuş, Tatar zulmünden korkup dağa kaçan bazı Boğdanlılar ise memlekette pek çok uygunsuz hareketlerde bulunmuşlardı. 1565'te Boğdan voyvodalığı yapan Aleksandr, Akkirman beyi Hasan Bey'in bu hareketlerini İstanbul'a bildirmiş, şikâyeti tahkik edilen voyvoda haklı görülmüştü. Söz konusu durum idare tarafindan hiç hoş karşılanmamış, neticede Akkirman beyi Hasan Bey'in yersiz tehditlerinden korkup dağa çıkarak ehl-i fesat gruba karışan Boğdan halkının 
daha fazla rencide edilmemesi ve vilayette yeniden huzur ortamı sağlanması için Hasan Bey ciddi şekilde uyarılmıştı. Kendisine vilayetteki ehl-i fesadı temizleyip kendi hallerinde olan halka dokunulmaması emredilmiş, aksi takdirde sancağın elinden alınıp başka birine verileceği bildirilmişti (BOA, A. DVNSMHM d. 6, s.?, hüküm: 73, 26 Muharrem 972/ 3 Eylül 1564). 1570'te Akkirman Tatarlarından bazı ehl-i fesat kimseler, Dinyester nehri geçidinde 22 kişinin koyunlarını gasp edip kendilerini esir etmiş, bu uygunsuzluk hakkında, Osmanlı merkez idaresi, Boğdan voyvodasının İstanbul'a yazdığı bir şikâyet mektubuyla bilgilendirilmişti. Akkirman beyinin subaşısı, eşkıya birliklerinin elinden 10 kişiyi kurtarmayı başarmışsa da diğerlerinin salıverilmesi için Bender ve Akkirman beylerine emirler gönderilmişti (BOA, A. DVNSMHM d.12, s., hüküm: 159, 20 Şevval 978/ 17 Mart 1571).

Voyvodaların istihbarî faaliyetlerdeki yararlılıklarına karşı Osmanlı idaresi de kayıtsız kalmamış, onlardan gelen şikâyetler araştırılıp değerlendirilerek bölge coğrafyasındaki huzur ve sükûn ortamının sürdürülmesine özen gösterilmişti. Mesela Eflak'ta birkaç zımmî, Cafer Çavuş yardımıyla kadıdan hüküm alarak, halktan bazı kimseleri suçsuz yere öldürmüş, ayrıca söz konusu Çavuşun, Eflak hazinesinden 25 bin akçe almak gibi başka bazı usulsüzlükleri ve ihanetleri, voyvoda ve reayayı mağdur etmişti. Bu uygunsuzluklar Eflak voyvodasınca merkezi idareye bildirilince kadı görevden azledilip adı geçen zımmîler ve Çavuş tutuklanmakla yetinilmemiş; Boğdan voyvodası da konu hakkında bilgilendirilmişti. Boğdan voyvodasından, eğer böyle bir durumla karşılaşırsa, içinde kendisinin mübaşir tayin edilmediği hükümlere itibar etmemesi, böyle hükümler ele geçirilirse toplayıp İstanbul'a göndermesi istenmişti (BOA, A. DVNSMHM d... 12, s.507, hüküm: 984, 6 Rebiyulevvel 979/29 Temmuz 1571).

İstihbaratın önem ve gerekliliğine vakıf olan Osmanlı idarecilerinin, seferleri genellikle gizlilik içerisinde tertip ettikleri görülmüştür. Bu gizliliğin tercih edilmesinde; yalnızca askeri hazırlıkların muhatabı olan devletlerin, girişilen hazırlıklardan haberdar olmalarının engellenmesi değil, süreçten kaynaklanan ve iç güvenliği tehdit eden isyan-eşkıyalık gibi meselelerin önüne geçilmek istenmesinin de payı vardır. İşte bu sürecin doğru bir şekilde yönetilmesinde voyvodaların istihbarî ve askerî yararlılıkları görülmüştür. Nitekim 1617'de Özi tarafina yapılacak seferden önce keşif ve dil alma vazifesiyle sefere memur edilmiş olan Eflak voyvodası Aleksandr'ın yokluğunu firsat bilip ayaklanma çıkaracağı duyulan olunan Şerban adlı asinin yakalanması için, Erdel voyvodası Petlan Gabor'a haber gönderilmiş, gerekli tedbirleri alarak söz konusu asinin yakalanması istenmişti (BOA, A. DVNSMHM d.82, s.148'den itibaren, hüküm: 142, 145,147, 7 Cemaziyelevvel 1027/2 Mayıs 1618).

Osmanlı Devleti'nin Balkanlarda uzun süren idaresinin başarısına, egemenliği altına aldığ bölgelerdeki hâkim unsurun genel temayülü doğrultusunda kararlar alarak, herhangi bir hoşnutsuzluğa mahal vermemesinin etkisi büyüktü. Bu temayülün ne yönde olduğunun sağliklı bir şekilde öğrenilmesinin bir yolu da voyvodaların sağladığı bilgi akışıydı. Bu bağlamda ilk olarak, bölgedeki hâkim unsur tarafindan benimsenen, aynı zamanda Osmanlı tarafına yakın olan beylerin tespiti voyvodaların uhdesine verilmiş gibiydi. Merkezi idare voyvodalardan, onlarla gizlice haberleşerek, hâsıl olan neticeyi İstanbul'a bildirmelerini isterdi. Mesela bunlardan biri olan ve Erdel Voyvodası vasıtasıyla mektubu gelen Macar Beylerinden Palaz Yanoş'un itaati hoşnutlukla karşılanmış; kendisine münasip bir mahalde serhat beyi olarak görevlendirilmek üzere Erdel'e gitmesi emredilmişti (BOA, A. DVNSMHM d.16, s. 268, hüküm: 523, 23 Zilkade 979/7 Nisan 1572). Bölgedeki karışıklıklar ve kriz durumlarının aşılmasında voyvodaların istihbarî vazifeleri biraz daha önemli bir hal alıyordu. Mesela Lehistan kralı ${ }^{3}$ ölüp (1576)

\footnotetext{
${ }^{3}$ Sigismund August'un 1572'de ölümüyle Jagiellonian Hanedanı sona ermiştir. 1572'den beri Lehistan kralları asiller sınıfının tamamı tarafından seçilmiştir. Osmanlı diplomasisi, Habsburg karşıtı adayların seçilmesini temin ederek ilk üç seçimde anahtar bir rol oynamıştır. Henry De Valais'in (1573-1574) kısa süren iktidarının ardından, Transilvanya palatini ve Osmanlı vasalı Stephan Bathory, Osmanlı’nın büyük desteği ile Lehistan tahtına seçilmiştir. Ayrıntılı bilgi
} 
memlekette otorite boşluğu ortaya çıkınca bölgedeki beylerden bazılarının kendilerini kral tayin ettirmek istediklerinin haber alınması üzerine Erdel voyvodasına; Erdel'in genel kanaati kendisinden yana ise ve şartlar ahde mugayir değilse kral olabileceği, Bekeş Gaspar dışında kim münasip görülürse tayin yapılacağı bildirilmişti (BOA, A. DVNSMHM d.27, s. 215, hüküm: 492, 20 Şevval 983/12 Ocak 1576). Ölüm veya başka sebeplerle, yeni bir voyvodanın göreve atanması gerektiğinde, bölgedeki genel kanaatin ne olduğu, kamuoyunun kimden yana tavır aldığ araştırılıp öğreniliyor, böylece uygun asilzadenin voyvodalığa getirilmesiyle, bölgede hoşnutsuzluk ve isyan çıkma ihtimali en aza indirilmiş oluyordu. Mesela Erdel Voyvodası Baturi Kristof'un vefat ettiği haberi alınınca Timeşvar Beyinden, bölgeye muktedir casuslar gönderip; voyvodanın ne zaman vefat ettiğinin, Erdel'deki genel durumun, halkın kimin voyvoda olmasını istediğinin, güzelce araştırılması istenmişti (BOA, A. DVNSMHM d.43, s.227, hüküm: 413, 24 Recep 988/4 Eylül 1580). Böylece Avrupa' daki hâkimiyet tesis edilirken bölgenin sosyo-kültürel, siyasî ve askerî dokusuna riayet edilmiş oluyordu.

Voyvodaların ve onlar adına Osmanlı merkez idaresiyle muhatap olan diğer vazifelilerin üstlenmiş oldukları sorumluluk, üst düzey bürokrasiyi ve devlet sırrı olabilecek önemli bilgiyi ihtiva ediyor olduğundan, söz konusu grubun hareketleriyle çok yakından ilgileniyordu. Nitekim Erdel'den elçi namıyla İstanbul'a gelip çeşitli incelemeler ve görüşmeler yaptıktan sonra firar ederek Eflak'a, ardından Erdel'e gittiği duyulmuş olan şahsın acilen yakalanıp İstanbul'a gönderilmesi için Eflak voyvodası uyarılmıştı. Söz konusu şahsın ne şekilde olursa olsun ele geçirilmesi, yakalanması için her ne yapılması gerekiyorsa yapılması, güvenilir adamlarla, sık1 tedbirler alınarak bir an önce İstanbul'a gönderilmesi yakalanamazsa özrünün asla kabul edilmeyeceği eklenmişti (BOA, A. DVNSMHM d... 72, s. 259, hüküm: 510, 9 Cemaziyelevvel 1002/ 31 Ocak 1594). Merkezi idare tarafindan casus olduğu konusunda şüphe duyulmayan bu şahsın yakalanması için sarf edilen çabada, voyvodaların yardım ve desteğine gereksinim duyulması, onların istihbarî hizmetler açısından oldukça mühim bir yer işgal ettiklerini gösteriyor.

\section{Madalyonun Öteki Yüzü: Karşı Casusluk}

İstihbarî açıdan pek çok yararlılığı olan voyvodaların, kimi zaman Osmanlı aleyhine casusluk yaptıkları da görülmüştür (Peçevî, 1982, s.146). 8 Temmuz 1538'de I.Süleyman'ın, Boğdan voyvodası V. Petru Rareş üzerine sefere çıkmasının nedeni voyvodanın Ferdinand hesabına casusluk yapmasıydı. Bu suç kapsamında Türk düşmanlarına paraca yardım yapıyor, Osmanlı müttefiki bulunan Polonya arazisine tecavüzlerde bulunuyor, ödemekle mükellef olduğu vergiyi vermekten imtina ediyordu. Daha önemlisi I. Süleyman'ın hesabına çalışan Venedik asilzadesi ve Sultanın gayri resmi siyasi müşaviri bulunan Alessio Gritti' yi astırmış, bununla da yetinmeyip Avusturya İmparatoru Ferdinand ile yaptığı gizli istişarelerle, Osmanlı aleyhine bir ittifak oluşturmak için girişimlerde bulunmuştu (Aksun, 1994, s.292). I. Süleyman bunun üzerine Boğdan üzerine sefere çıkmış, ancak istihbaratın önem ve gerekliliğine vakıf olduğu ittifakla kabul edilen Sultan, sefer hazırlığı esnasında kimseyi bilgilendirmemiş, 1538'de İstanbul'dan hareket ederek Edirne'ye kadar geldiğinde ancak o zaman Boğdan'a sefere çıkıldığı anlaşılmıştı (Uzunçarşıl1, 1954, s.83). Seferde kendisine özellikle iştirak etmesini istediği Karakum Hanı Sahip Giray Han'dan da Petru Rareş hakkında detaylı malumat almış, (Guboglu, 1986, s.778) asi voyvoda kısa sürede yenilgiye uğratılmıştı. Rareş savaşta yenilerek Macar Krallığına sığınmış 1 y1l 6 ay kadar kaldığı süre zarfinda mezalim görmüştü. Karısı Elana'ya Sırpça bir mektup yazdırarak Sultan'dan affını talep eden voyvodanın bu isteği I.Süleyman tarafından geri çevrilmemiş, kendisinin affedildiğinin bildirildiği bir mektupla Macar Kralı'na, Sultan tarafından

için bkz. Dariusz Kolodziejezk, “1795'e Kadar Osmanl1-Leh İlişkilerinin Karakteri Üzerine Bazı Tespitler” Türkler, C.IX, Ankara 2002, s. 680-681. 
bir elçi gönderilmiştir. Sultanın elçisi ve Macar Kralı arasında uzun süren müzakereler sonucunda, Kral Rareş'i serbest bırakmayı kabul etmiş, İstanbul'a gidip Sultan'dan tekrar af dileyen Rareş yeniden Boğdan tahtına oturmuştur (Ekrem, 1993, s.16).

1 Ocak 1577'de Lehistan tahtına II. Rodolphe (Radolf) oturmuş, Erdel'e Osmanlı'ya yakınlığı bulunan Battori voyvoda olarak seçilmişti. Bu gelişme Avusturya ve Rusya'nın Lehistan'1 parçalayıp, taksim etme hususunda girişmiş oldukları gizli anlaşmaların, Battori sayesinde ortaya çıkarılmasını sağlamıştı. Ancak ilerleyen süreçte tereddüt içinde kalan voyvoda; Avusturya'nın tahrik ve tekliflerine kapılarak çift taraflı casusluk yapmaya kalkışmış, Papa'nın Kutsal ittifakına katılmıştı (Aksun, 1994, s.371, 418). Avusturya'nın himayesi altında bulunan uskok (kaçak) eşkıyasının Bosna serhaddine yönelik tecavüzleri ve buna karşı Bosna Beylerbeyi Hasan Paşa'nın Avusturya kalelerine yönelik harekâtı yüzünden Avusturya ve Osmanlı arasında II. Selim zamanında imzalanan ve yaklaşık 25 yıldır yürürlükte olan anlaşma 1593 'te bozulmuştu. Böylece Avusturya ile yaklaşık 13 yıl sürecek olan savaşlar dönemi başlamıştı. Papalık önderliğinde Hiristiyan devletlerarasında Osmanlı Devleti aleyhine gizli bir kutsal ittifak kurulmuştu. Bu ittifaka 1594'te, o zamana kadar Osmanlı Devleti'ne tâbi olan Erdel, Eflak ve Boğdan voyvodaları da katılmışlar; Eflak voyvodası Mihal (Mihai Viteazül) ve Boğdan voyvodası Aron Tranul Osmanlı Devleti'ne isyan ederek memleketlerindeki Müslüman tüccar ve az miktardaki Osmanlı askerlerine karşı katliama girişmiş ve Müslüman yerleşim birimlerini yakıp yıkmışlardı. Erdel Voyvodası Batori Sigismund da bunlara yardım etmişti (82 Numaralı Mühimme Defteri, 2000, s. IX).

Özi Beylerbeyi İskender Paşa'nın rey’i ile bir iki defa Avusturya'ya elçilik vazifesiyle gönderilmiş, hatta Sultan Ahmed zamanında Zitvatoruk Anlaşması'nın yenilenmesi maksadıyla 1617'de Viyana'ya giden Ali Bey'e refakat etmiş Boğdan voyvodası Gratiyani Gaspar (Gaşir)'ın öldürülmesinin nedeni Lehlilere casusluk yapmasiydı (Rasim, 2000, s.224-225 ). Naxos dukalığından Boğdan voyvodalığına getirilen Gratiani'in, Osmanlı aleyhine, Lehistan'a karşı casusluk yapmasından dolayı üzerine sefer düzenlenmişti (1620). Erdel Prensi Bethlen Gabor'un Bab-1 Ali'ye gönderdiği, Kazaklar ve Lehliler hakkında yapılmış istihbarî çalışmaları içeren mektubu ele geçiren voyvoda, bu mektubu getiren haberciyi tutuklatmış, söz konusu mektubu, Osmanlı'ya karşı tahrik kastıyla Lehistan'a bildirmişti (Aksun, 1994, s.45).

IV. Mehmed devrinde (1648-1687) Osmanlı istihbaratının yönünü belirleyen gelişme, Osmanlı himayesinde bulunan Erdel Kralı II. Rakoçi'nin Lehistan krallı̆̆ını ele geçirmeye yönelik isyan hareketi olmuştu. İsyana destek verenler arasında Eflak-Boğdan voyvodalarının olduğu Melek Ahmed Paşa'nın dil olarak tuttuğu Kazaklardan öğrenilmişti. Diller kanalıyla sağlanan istihbaratın teyit edilmesi için voyvodalıklar tarafına casuslar gönderilmişti. Bu sayede voyvodaların II. Rakoçi'den aldıkları destekle Osmanlı ordusunu bir su geçidinde basmak fikrinde oldukları öğrenilmişti (Yüksel 2013, s.68 ).

Karşı casusluk, isyan gibi meselelerin doğurduğu gelişmeler Osmanlı merkezi idaresinin onlara olan güvenini sarsacak; ilerleyen süreçte voyvodalar, bölge yerlilerinden değil de İstanbul'dan, Osmanlı'ya hem coğrafi hem de kültürel olarak daha yakın olan Fenerli Rumlar arasından seçilmeye başlanacaktır, bu süreç 1821 Yunan İsyanına kadar devam edecektir (Aksun, 1994, s.323; Yüksel 2013, s. 164). Bab-1 Ali tarafından görevlendirilen ve 110 yıl görevde kalacak olan bu beyler, Avrupa'yı tanıyan, siyasetten haberdar, dil biler, güvenilir kişiler arasından seçilmiştir. Fenerli bu voyvodalar için, yönetici veya vali anlamına gelen "Hospodar" adı kullanılmış; Bab-1 Ali'nin Balkanlardaki en önemli temsilcileri olmuşlardır. Voyvodalıklarda istikrarın sağlanması için merkezi idare, hospodarların 3 senede bir değiştirilmesini ve iyi hizmet görenlerin hizmet sürelerinin uzatılmasını kararlaştırmıştır. Boğdan'a atanan ilk Fenerli voyvoda Divan-1 Hümayun tercümanı olan Nikolaye Mavrokordat, 1716 senesinde Sultan III. Ahmed'in tevcihiyle Serban Kantakuzino'dan sonra Eflak hospodarlığına tayin olmuştur (Pala, 2009, s. 30). 
Görüldüğü üzere istihbarat konusunda faal birer aktör durumunda olan voyvodalar, devletin özellikle dış politikasında olumlu yahut olumsuz pek çok etkiye sahip olmuşlardı. Osmanlı'nın Avrupa'ya bakan yüzü ve Balkanlardaki temsilcisi konumunda olan voyvodalar sadakat ve özveri ile hizmet ettikleri durumlarda, idarenin; askeri, mali ve siyasi açıdan en önemli destekçileri olmuşlardı. Hal böyleyken tersi durumda yaratmış olabilecekleri tehdidi tahmin etmek kolaylaşıyor. Nitekim bu voyvodalardan biri olan Yuvan'ın isyanı sürecinde kayıtlara giren olaylar; onların askerî, malî ve istihbarî kaynaklarını Osmanlı'ya karşı kullandığında ne gibi sonuçlar doğurduğuna dair dikkat çekici detaylar barındırmaktadır.

\section{Voyvoda Yuvan İsyanından Osmanlı İstihbaratına Yansıyan Bazı Notlar}

Hasım veya hasım olması muhtemel tarafin askeri hazırlıklarını haber alıp bildiren voyvodaların yararlılıkları her daim merkezi idare tarafından elbette ki takdirle karşılanmıştır. Ancak bunlardan en dikkat çekici olanı kendisinden önce isyan eden Boğdan voyvodası Boğdan'ın yaptığı uygunsuzlukları merkezi idareye bildiren Yuvan'ın bu istihbarî hizmetinin takdir edilmesi olabilir. Nitekim isyan etmeden birkaç ay önce İstanbul'a sunmuş olduğu raporla; voyvoda Boğdan'ın Lehistan tarafından aldığı destekle isyan ettiğini, asi voyvoda Boğdan'ın üzerine gönderilen kuvvetlere yenik düşüp yaralı olarak kaçarak, kardeşi ile beraber Lehistan'a sığındığını bildirmişti. İki defa istenmesine rağmen Leh kralı tarafından bu isteğin geri çevrildiği, asi Boğdan'a yardım eden bazı bolarlar ile eski voyvoda arasında gidip gelen mektupların ele geçirildiği ve ihanetleri vaki olan bolarların cezasının verildiği de eklenmişti. Asi Boğdan'ın, Leh kralı yardımıyla Boğdan üzerine yürümek niyetinde olduğu da, Yuvan'ın casusları aracılığıyla edinip İstanbul'a arz ettiği malumat arasındayd. Voyvoda Yuvan'a cevaben, Lehistan tarafindan casuslarını eksik etmeyip edindiği malumatı İstanbul'a bildirmekten geri durmamasının tembih edilmesi, ayrıca Eflak, Erdel voyvodaları ile Niğbolu, Silistre, Bender beylerine bu konuda Yuvan'a destek vermelerinin emredilmesi istihbaratının özünde bulunan belki de ironik dinamiktir. (BOA, A. DVNSMHM d.12, s.229'dan itibaren, hüküm: 1128, 1134, 1139, 1143, 1165 , 1170, 1171, 1191, 1205, 25 Zilkade 979/ 9 Nisan 1572- 6 Zilhicce 979/ 20 Nisan 1572 tarihleri arasinda)

Esasen Yuvan, selefi olan voyvoda Boğdan'ın (1568-1572) Boğdan'a zarar vermesi, defalarca uyarılmasına rağmen reayayı rencide ve mağdur etmesi, kadimden beri hizmette olanların yerine hariçten adamları idareye getirmesi gibi uygunsuz davranışlarından dolayı azledildiği için göreve atanmıştı (BOA, A. DVNSMHM d... 21, s.5, hüküm: 34, 28 Zilhicce 979/ 12 Mayıs 1572). Azledildikten kısa süre sonra isyan eden Boğdan'ın yakalanması için de istihbarî ve askeri vazifeler üstlenmişti. Ancak görevde kaldığı kısa süre zarfinda selefiyle hemen hemen aynı hatalara düşmüş; Boğdan boyarları ve ahalisine zulmetmesi, boyarlardan bazılarını katlederek mallarını gasp etmesi gibi uygunsuzlukları azline, azli ise isyanına sebep olmuştu (BOA, A. DVNSMHM d. 24, s.40, hüküm: 115, 22 Rebiyülahir 981/ 21 Ağustos 1573).

Azledilen Boğdan voyvodası Yuvan; Bender Beyi ile İstanbul'a ayrı ayrı mektup göndermişti. Bender Beyi'ne Kili Kalesi tamiri için gerekli olan keresteyi göndermekte olduğunu bildirmişti. Merkeze ise; Boğdan haracının, yerine atanan voyvoda Petre'ye verilmekte bir kargaşa çıktığı için, haracın Mustafa Çavuşla gönderildiğini, kendisinin de yakın bir zamanda hareket ederek İstanbul'a gelmek üzere olduğunu arz etmişti (BOA, A. DVNSMHM d. 24, s.142, hüküm: 387, 28 Zilhicce 981/ 4 Nisan 1574). Ancak merkezi idare bu şüpheli davranışın peşine düşüp Akkirman Beyi ve kadısına mektuplar göndererek Kili Kalesi tamiri için kereste işine vazifeli olarak gönderilen Mustafa Çavuş'a Boğdan'a gitmesi için emir verilmediği halde oraya neden gittiğinin gizli bir şekilde araştırılmasını emretmiş, Yuvan'ın Boğdan voyvodasından para alıp almadığının tahkik edilmesini istemişti (BOA, A. DVNSMHM d. 24, s.162, hüküm: 382, 15 Safer 982/ 6 Haziran 1574). Yapılan tahkikat sonucunda; Yuvan'1n, Boğdan'a giden koyun 
tacirlerinden zorla aldığ bin filori) müteşekkil olan emtiayı (BOA, A. DVNSMHM d.26, s. 211, hüküm: 595, 26 Cemaziyelevvel 982/ 13 Eylül 1574. $)^{4}$ Hotin Kalesi'ne bıraktığı, kendisinin de başka bir yere kaçmakta olduğu casuslar aracılığıyla öğrenilmişti (BOA, A. DVNSMHM d. 26, hüküm: 1, s. 13, 17 Safer 982/8 Haziran 1574).

Eflak voyvodasından; diğer beylerle beraber Boğdan'a casuslar yollaması ve hep beraber hareket ederek söz konusu Yuvan'ın ve eşyasının ele geçirilmesi istenmişti (BOA, A. DVNSMHM d...24, s.163, hüküm: 387, 28 Zilhicce 981/ 4 Nisan 1574). Haber, yeni atanan Boğdan voyvodas1 Petre'ye de ulaştırılmış; asi Yuvan'ın bütün emtiasını Hotin Kalesi'ne sakladığı, bir firsatını bulup firar edeceği konusunda bilgilendirilmişti. Hemen diğer beylerle üzerine gidilip tutuklanması ve Hotin Kalesi'ne hapsedilmesi, kalenin içine 50 kadar Müslüman muhafız beşli koyarak ulufelerini Boğdan hazinesinden vermesi emredilmişti (BOA, A. DVNSMHM d. 24, s.161, hüküm: 383, 28 Zilhicce 981/ 4 Nisan 1574; BOA, A. DVNSMHM d. 24, s.86, hüküm: 296, 20 Zilhicce 981/ 12 Nisan 1574). Yalnızca Boğdan voyvodasından değil; Erdel voyvodası (BOA, A. DVNSMHM d. 24, s. 86, hüküm: 298, 20 Zilhicce 981/ 12 Nisan 1574; BOA, A. DVNSMHM d. 24, s.172, hüküm: 412, 3 Muharrem 982/ 25 Nisan 1574), Budin beylerbeyi, Bender (BOA, A. DVNSMHM d.24, s.172, hüküm: 410, 3 Muharrem 982/ 25 Nisan 1574), Silistre ve Niğbolu Beyleri (BOA, A. DVNSMHM d.. 24, s.142, hüküm: 295, 20 Zilhicce 981/ 12 Nisan 1574) ve Leh kralından söz konusu asinin yakalanması ve eşyasına el konulması istenmişti (BOA, A. DVNSMHM d... 24, s. 163, hüküm: 387, 8 Recep 981/3 Kasim 1573).

Leh Kralı Henriko'ya; eski kral ölünce, Lehistan'a dikilen gözlerin alınan tedbirlerle men edilip kendisinin tahta geçmesi için yardım edildiği hatırlatılmış, kendisine, Boğdan'daki isyancı voyvodanın Lehistan'daki beyler tarafından himaye edilip Avusturya'ya kaçmasına yardım edildiği bilgisi verilmişti. Osmanlı merkez idaresi, kendi taraflarından sulhu bozacak bir davranış olmamasına rağmen asi voyvodanın tecavüzü vukua geldiğinde, voyvodaya Leh tarafından yardım edildiğini, Krala yazılan bir mektupla bildirmişti. Söz konusu yardımı Akkirman üzerine gidildiğinde ele geçirilen diller doğrulamış ve beylerinden asiye gönderilen mektuplar ele geçirilmişti (BOA, A. DVNSMHM d..26, s.90, hüküm: 232, 3 Rebiyyulevvel 982/23 Haziran 1574). Yuvan'a sözde yardım için ama gerçekte Boğdan voyvodalığını ele geçirmek için harekete geçen Laski ${ }^{5}$ adındaki Bey'in Boğdan'a gittiğinden haberdar olunduğu, eğer aradaki dostluğun devamı isteniyorsa Laski'nin cezalandırılması ve Yuvan Lehistan'a askerleriyle beraber iltica ederse yakalanarak kendilerine teslim edilmesi istenmişti (BOA, A. DVNSMHM d... 24, s.236, hüküm: 823, 3 Safer 982/ 25 Mayıs 1574).

Neticede asi voyvoda yakalanarak Rodos'a hapse gönderilmişti (BOA, A. DVNSMHM d. 24, s. 163, hüküm: 387, 20 Zilhicce 981/20 Nisan 1574). Ancak kayıtlardan Yuvan'1n hapiste de casusları vasıtasıyla dışarı ile haberleştĭgi, halkı kışkırtarak vilayette bir isyan çıkmasına teşvik için çeşitli girişimlerde bulunduğu takip ediliyor. Boğdan voyvodası Petre'nin İstanbul'a mektup göndererek Avusturya dolaylarından kaçıp Eflak'a giden ve hâlen Eflak'ta hatta bizzat Eflak

Voyvodasının yanında bulunan Boğdan casuslarının varlığından söz etmesi üzerine; Tercüman Mehmet Bey vasıtasıyla, Eflâk voyvodasına bir emir gönderilmişti. Eflak voyvodasından; casusların, Eflak vilayetinde serbestçe dolaşıp zulüm ve fenalıklarda bulunmaktan başka Rodos'ta

\footnotetext{
${ }^{4}$ İsyan etmeden önce 10 bin filori göndermekte olan Yuvan, daha sonra 50 bin filori göndermeyi taahhüt etse de göndermemiştir. Yuvan'dan sonra getirilen Voyvoda Petre'den her sene 50 bin filori göndermesi istenmişti. Bkz. BOA, A. DVNSMHM d...26, s.211, hüküm: 595, 26 Cemaziyelevvel 982/ 13 Eylül 1574.

${ }^{5}$ Büyük Leh soylularından olan Albert Lacki, Leh soylularının Osmanlı'ya tabi sınır prensliklerinde Osmanlı karşıtı faaliyetler yaptığı hakkında en iyi örnekler arasındadır. Lacki (Laski) Eflak-Boğdan sınırlarında boyarları kışkırtıp kendine bağlayarak Osmanlı'yı uzun süre uğraştırmıştı. Osmanlı Devleti, bu Leh sınır güçlerine karşı bölgedeki TatarKırım birliklerini harekete geçirmişti. Ayrıntılı bilgi için bkz. Yücel Öztürk, "Osmanl1-Lehistan İlişkilerinde Savaş, Diplomasi ve Ticaret”, Karadeniz Araştırmaları XIV/55, Güz 2017, s.225-252.
} 
hapis bulunan Boğdan eski voyvodası Yuvan'ın mektuplarını dolaştırıp adamlarını toplayarak halkı kışkırtıp tahrik etmelerinin önlenmesi istenmişti (BOA, A. DVNSMHM d..7, s. 12, hüküm: 1985, 2 Rebiyyülevvel 976/25 Ağustos 1568; BOA, A. DVNSMHM d.24, s. 141, hüküm: 387, 20 Zilhicce 981/20 Nisan 1574).

Bir şekilde hapisten firar etmeyi başaran Asi Yuvan'ın yakalanması için Bender, Niğbolu, Silistre beylerine ve Erdel Voyvodasına emirler gönderilmiş; neticede 1574 'te asi voyvoda ile muharebe sahasında karşı karşıya gelinmişti (BOA, A. DVNSMHM d.24, s. 142, hüküm: 296, 20 Zilhicce 981/ 12 Nisan 1574). Yuvan'1n Bender'e girmesi üzerine, Bender Sancakbeyi, Çavuşbaşısı Tuhtar vasıtasıyla İstanbul'a haber gönderip asinin üzerine gittiğini bildirmişti. Durum merkezi idare tarafindan memnuniyetle karşılanarak Bender Sancakbeyine destek olmak üzere; Rumeli Beylerbeyi, Dergâh-1 Ali Kapıcılarbaşısı Sinan, Boğdan voyvodası Petre, Niğbolu, Vidin beyleriyle Eflak ve Erdel askerleri, Silistre, Çirmen, Vulçıtrın, Alacahisar Selanik, Prizrin, İlbasan, Ohri ve İskenderiye ve Köstendil Beyleri gibi pek çok Sancakbeyi görevlendirilmiş, (BOA, A. DVNSMHM d..26, s. 18, hüküm: 52; 25 Safer 982/16 Haziran 1574 ) ${ }^{6}$ söz konusu voyvodanın yakalanıp hakkından gelinmesi ve ona tabi olan Boğdanlı, Lehli vesaireye ibret olması için katledilmesi istenmişti (BOA, A. DVNSMHM d..26, s.90, hüküm: 232, 3 Rebiyyulevvel 982/23 Haziran 1574). Seret Suyu üzerinde Asi voyvoda Yuvan ile yapilan muharebe sonucu askerleri bozulmuş kendisi de öldürülmüş̧ü (BOA, A. DVNSMHM d..26, s.32, hüküm: 87, 29 Safer 982/20 Haziran 1574).

Vidin Beyi Mustafa Bey'den Yuvan'ın bozulan askerlerinden kadın ve işe yarar olmayanların salıverilmesi yarar olanların her kimde bulunursa 300-400'er akçeye alınarak gemiyle veya karadan resmi muhafaza ile İstanbul'a gönderilmeleri, Yuvan'a tabi olmayan Boğdanlıların kadın ve çocukların serbest bırakılması istenmişti (BOA, A. DVNSMHM d...26,

s.34, hüküm: 91, 29 Safer 982/20 Haziran 1574; BOA, A. DVNSMHM d... 26, s.107, hüküm: 276, 4 Rebiyülahir 982/24 Temmuz 1574). Ayrıca ondan kalan bazı mühimmatın sağlam olanlarının da münasip mahallere yollanması için emirler gönderilmişti (BOA, A. DVNSMHM d... 26, s.115, hüküm: 298, 7 Rebiyülahir 982/ 27 Temmuz 1574; BOA, A. DVNSMHM d...28, s.303, hüküm: 759, 1 Şaban 984/24 Ekim 1576; BOA, A. DVNSMHM d... 26, s.121, hüküm: 318, 10 Rebiyülahir 982/ 30 Temmuz 1574). İsyan bastırılınca Yuvan'ın yakın adamlarının da peşine düşülmüş; yakalanıp hapsedilenlerin İstanbul'a sıkı tedbirlerle ve ifşa edilmeden gönderilmesi istenmişti. Bunlardan Yuvan'ın yakın adamı olan Dobrava'nın yakalanmasına özellikle ihtimam gösterilmiş, hapsedildiği işitilen Dobrava'nın mahfuzen İstanbul'a gönderilmesi için Erdel voyvodası vazifelendirilmişti (BOA, A. DVNSMHM d...26, s. 97, hüküm: 259, 1 Rebiyülevvel 982/21 Haziran 1574) Ayrıca Boğdan Voyvodasına da söz konusu destekçinin ele geçirilmesi için emri şerif gönderilmişti (BOA, A. DVNSMHM d... 26,s. 243, hüküm: 712, 14 Cemaziyelahir 982/1 Ekim 1574).

Yuvan muharebesinde yararlılık gösteren beylere tımar ve zeamet terakkileri yapıldığı; muharebede yarar dil getirenlerin taltif edildiği de belgelere yansıyor. Mesela eski Niğbolu Beyi olan Vidin Beyi Mustafa Bey, maiyetindeki 20 nefer tımarlı ile 15 nefer garib yiğitlerin taltifini rica edince bu isteği geri çevrilmemiş; tımarlıların tımarlarına terakki yapılmış, garib yiğitlere ise tımar tahsis edilmişti (BOA, A. DVNSMHM d..25, s.179, hüküm: 1710, 23 Safer 982/14 Haziran 1574). Silistre Beyi Davud Bey'in maiyetinde bulunan, 151 garib yiğit, 1 zaim ve 15 tımarlı sipahi ve 11 yaralı askeri unutulmamış; Zaim Behram, Dergâh-1 Ali müteferrikalığına ilhak olunmuş, tımarlı sipahilerin tımarlarına terakki yapılmış, garib yiğitlere tımar verilmişti (BOA, $A$. DVNSMHM d.25, s.192, hüküm: 1870, 15 Rebiyulevvel 982/5 Temmuz 1574; BOA, A.

\footnotetext{
${ }^{6}$ Boğdan Voyvodası Petrenin yanında 1500 yeniçeri, 25 darbzen (56,5 kg ağırlığında, 160 gramlık küçük mermiler atabilen top cinsi) bulunuyordu. Bkz. BOA, A. DVNSMHM d..26, s. 18, hüküm: 52; 25 Safer 982/16 Haziran 1574.
} 
DVNSMHM d.25, s.192, hüküm: 1871, 15 Rebiyulevvel 982/5 Temmuz 1574. Timar ve zeamet terakkileri için bkz. BOA, A. DVNSMHM d... 25, hüküm: 1710, 1754, 1781, 1859,1870, 1871, 1872, 1873, 1874, 1877, 1884, 1906, 1907, 1908, 1911, 1925, 1926, 1945, 1947, 1958, 1965, 1971, 1977, 1990, 1992, 1993, 2004, 2029, 2048, 2055, s.192- 218 aras1, 15 Rebiyulevvel 982/5 Temmuz 1574- 4 Rebiyülahir 982/ 24 Temmuz 1574 tarihleri arasında 30'dan fazla hüküm bulunmaktadır).

Zeamete mutasarrıf olan Ahmed'in, asi Yuvan muharebesinde düşmanın bir koluna hücum edip hezimete uğratmakta yararlılığı görüldüğünden çavuşluk ricasının geri çevrilmemesi, Vulçitrin sancağında tımarı olan Divane Hüseyin'in, Murad Gazi'nin ve Divane Malkoç Bey'in yarar dil getirmelerinden dolayı kendilerine zeamet terakki edilmesi ise konu ile ilgili olarak eklenebilecek misallerden yalnızca birkaçıdır (BOA, A. DVNSMHM d... 25, s.192, hüküm: 1872, 15 Rebiyulevvel 982/5 Temmuz 1574; BOA, A. DVNSMHM d... 25, s.196, hüküm: 1908, 16 Rebiyulevvel 982/6 Temmuz 1574; BOA, A. DVNSMHM d... 25, s.218, hüküm: 2055, 3 Rebiyülahir 982/23 Temmuz 1574; BOA, A. DVNSMHM d... 25, s.222, hüküm: 2082, 4 Rebiyülahir 982/24 Temmuz 1574)

Voyvodalar ve casusluk özelinde mühim bilgiler içeren Yuvan isyanı hadisesinin halledilmesi yolunda ciddi istihbarat çalışmaları göze çarpmaktadır. Merkezi idarenin en başta Yuvan'ın haraç verme ve kereste gönderme vazifelerini geciktirmesi ve görevli olmadığı halde Mustafa Çavuşla haracı gönderdiğini ifade eden mektuptan şüphelenilerek durumun araştırılması için Akkirman beyi ve kadısına gizlice haber gönderilmesi Yuvan'ın gerçek niyetinin öğrenilmesini sağlamıştı. Leh beylerince himaye edilmesine rağmen yakalanılıp hapse atılması yine civardaki tüm voyvoda, beyler ve devletlerle olan yoğun bürokratik muhabere ve çeşitli istihbarat kanallarının kullanılmasıyla mümkün olmuştu. Hapiste kaldığı kısa süre zarfında casusları vasıtasıyla bir isyan çıkarma niyetinde olduğunun öğrenilmesi de karşı istihbarat yürüten merkezi idarenin önemli bir diğer başarısıdır. Her ne kadar hapisten kaçmayı başarıp muharebe sahasında karşı karşıya gelinse de durumdan haberdar edilen beylerden; Bender Sancakbeyinin ilk müdahaleyi yapıp durumu İstanbul'a bildirmesi, isyanın büyümeden önlenmesinde ve merkezden büyük bir birliğin desteğinin hemen gönderilerek tehlikenin ortadan kaldırılmasına etki etmişti. Askeri müdahale sonucu isyan bastırıldıktan sonra; yakın adamı Dobrava'nın, eşi ve kayınpederinin yakalanması için sürdürülen faaliyetler, Lehistan'da bir kasaba zabiti tarafından Yuvan'ın eşi ve kayınpederinin alıkonulduğunun haber alınması gibi gelişmeler; Osmanlı istihbaratının henüz 1500 'lerin sonunda arz ettiği genişlik açısından bir başka dikkat çekici detaydır. Son olarak o dönem Lehistan ile Osmanlı arasında sulh olmasına rağmen gizlice isyana destek veren Lehli bazı beylerin Yuvan'a yazılmış destek mektuplarının ele geçirilmesi ve Akkirman üzerinden alınan dillerden bu desteğin doğrulanması da Osmanlı istihbaratının çok yönlü ve etkili bir şekilde kullanıldığının açık birer göstergesidir. (BOA, A. DVNSMHM d... 26, s.90, hüküm: 232, 28 Rebiyülahir 982/17 Ağustos 1574)

\section{Sonuç}

Osmanlı'nın Balkanlardaki ve daimi elçilerin olmadığı vakitlerde Avrupa'daki temsilcisi görünümünde olan voyvodaların, idareye olumlu katkısı veya olumsuz pek çok etkisi olmuştur. Bölgedeki Osmanlı egemenliği henüz tam olarak yerleşmemişken, söz konusu coğrafyadaki kültürel yapının idrak edilmesi, böylelikle, sahadaki hâkimiyetin tesis edilmesi için bu yerel beylerden istifade edilmişti. Voyvodalıklar Osmanlı merkezi idaresine; askeri, stratejik ve mali açıdan da fayda sağlıyordu. Savaş zamanlarında Osmanlı birlikleriyle hareket etmeleri, devletin dış politikasında müşterek bir siyasi yapı konumunda bulunmaları, onları askeri açıdan dost ve müttefik bir vasal haline getiriyordu. Bu ise hasım olunan devletlere karşı bir nevi stratejik 
üstünlük kazandırıyordu. Yıllık haraç ödemeleri, voyvoda seçilebilmek için Sultan ve devlet adamlarına sunmuş oldukları hatırı sayılır kıymette hediyeler, sefer organizasyonlarında çıkarılan ivedi emirlerle kendilerinden temin edilen; erzak (özellikle bal ve yağ), zahire, binek hayvanı, haraç gibi aynî ve nakdî yardımlar devleti mali açıdan destekleyen önemli bir gelir kalemiydi.

Osmanlı Devleti'nin menfaatleriyle çelişen devletler hakkında bilgi edinerek merkezi idareye sunmaları onları diplomatik istihbarat, bölgede herhangi bir askeri hareketlilik söz konusu olduğunda mevcut durumu vakit kaybetmeden İstanbul'a bildirmeleri ise askeri istihbarat özelinde oldukça mühim bir pozisyona taşıyordu. Onlardan ayrıca isyan, eşkıyalık, reayaya karşı işlenen suçlar gibi iç istihbaratı havi konularda yardım ve destek alınıyordu. Casusluk ve diğer istihbarat kanallarıyla, gizlilik içerisinde sürdürdükleri izleme ve inceleme faaliyetleri neticesinde edindikleri istihbaratı ayrıntılı bir rapor halinde Osmanlı idare merkezine ulaştıran voyvodaların üstlendikleri sorumluluk aldıkları riskle doğru orantılıydı. Voyvodaların bu özverili çalışmalarına Osmanlı idaresi de kayıtsız kalmıyor, onlardan gelen şikâyet dilekçeleri mutlaka değerlendiriliyor, konu ile alakalı olarak gerekli tahkikat yapıldıktan sonra suçu tespit edilmiş olanlara cezai yaptırım uygulanıyordu.

Tüm bunların yanında merkezi idare ile bir şekilde husumeti olan voyvodalar, aynı stratejik pozisyonu Osmanlı aleyhine kullanabiliyordu. Yuvan örneğinde olduğu gibi azledileceğini duyunca voyvodalığın hazinesini çalıp eyaletten kaçması, diplomatik yakınlığını kullanarak Lehli bazı beylerin desteğini alması, casusları vasıtasıyla eyalette isyan çıkarıp hapisten firar etmek için şartları uygun hale getirmeye çalışması sebep olduğu diplomatik, askeri ve tabi ki mali zararların birkaçıdır. Söz konusu isyan sırasında Lehistan -Osmanlı arasındaki diplomatik ilişkiler gerilmiş, Lehistan Kralı'na, kral olabilmek için kendi desteklerine muhtaç olduğu hatırlatılmak zorunda kalınmıştı. Asi Yuvan'a destek veren Lehli beylerin cezalandırılması konusunda 1srarcı olunmuş bu ise iki devlet arasında soğuk rüzgârlar esmesine neden olmuştu. Üstelik muharebe sırasında kullanılan mühimmat ve sevkiyatı yapılan asker sayısı değerlendirilecek olursa Osmanlı tarafının mali kaybı azımsanmayacak kadar fazlaydı.

Bununla birlikte isyan hadisesi ve öncesinde yaşanan olaylar Osmanlı istihbaratı açısından ciddi bir canlılığa işaret etmektedir. Voyvodanın firar ettiği kalenin, kendisine yardım eden beylerin tek tek isimlerinin, hapisteyken dışarı ile haberleşmesini sağlayan casuslarının tespit edilmesi Osmanlı istihbaratının çok yönlü ve etkili bir şekilde kullanıldığını kanıtlar niteliktedir. Voyvodanın yakalanması esnasında sürdürülen istihbarat çalışmalarında; voyvoda ve diğer beyler, elçilik, casusluk gibi kanallar ve karşı casusluk, dil alma gibi stratejilerden istifade edilmiştir. Hakkında malumat edinilmeye çalışılan voyvoda Yuvan'ın isyan hadisesi özelinden bakılınca onların pozisyonlarına ve Osmanlı idaresinin henüz 1500'lerin sonundaki istihbarat stratejilerine dair mühim ipuçları görülmüştür. 


\section{Kaynakça}

\section{A- Arşiv Belgeleri}

\section{Başbakanlık Osmanlı Arşivi (BOA) \\ Mühimme Defterleri \\ $3,5,6,7,12,14 / 1,16,21,24,25,26,27,43,64,72$.}

\section{B- Yayınlanmış Arşiv Belgeleri}

82 Numaralı Mühimme Defteri (1026-1027 / 1617-1618), Başbakanlık Devlet Arşivleri Genel Müdürlüğü Osmanlı Arşivi Daire Başkanlığı Yayın Nu: 47, Ankara 2000, s. IX.

\section{C- Kaynak Eserler ve Araştırmalar}

Aksun, Z.N.(1994). Osmanlı Tarihi, I. İstanbul: Ötüken.

Çiftçi, C. (2010) Bâb-1 Âlî’nin Avrupa'ya Çevrilmiş İki Gözü: Eflak ve Boğdan'da Fenerli Voyvodalar (1711-1821). Uluslararası İlişkiler. S. 26, ss. 27-48.

Ekrem, M.A. (1993). Romen Kaynak ve Eserlerinde Türk Tarihi I Kronikler. Ankara: TTK. Guboglu, M. (1986). Kanuni Sultan Süleyman'ın Boğdan Seferi ve Zaferi. Belleten. S.198, ss. 727-805.

Kantemir, D. (1979). Osmanlı İmparatorluğu'nun Yükseliş ve Çöküş Tarihi II. Özdemir Çobanoğlu (Çev.). Ankara: Kültür Bak.

Kolodziejezk, D. (2002). 1795'e Kadar Osmanl1-Leh İlişkilerinin Karakteri Üzerine Bazı Tespitler. Türkler Ansiklopedisi içinde (c.9, ss. 679-685) Ankara: Yeni Türkiye.

Maxim, M. (2013). Voyvoda. İslam Ansiklopedisi içinde (c.43, ss. 127-129). İstanbul: Türkiye Diyanet Vakfi.

Müneccimbaş1 A. L. (1974). Müneccimbaş1 Tarihi II. İsmail Erünsal (Çev.). İstanbul: Kervan.

Öztürk, Y. (2005). 1559-1563 Erdel- Eflak- Boğdan Olayları ve Dimitriy Vişnevetskiy. Türklük Araştırmaları Dergisi, S.17, ss. 55-95.

Öztürk, Y. (2017). Osmanl1-Lehistan İlişkilerinde Savaş, Diplomasi ve Ticaret. Karadeniz Araştırmaları, S. 55, ss. 225-252.

Pala, N. (2009). Eflak ve Boğdan'da Osmanlı Hâkimiyeti ve Fuad Efendi'nin Layihası (Yayınlanmamış Yüksek Lisans Tezi). Dumlupınar Üniversitesi/Sosyal Bilimler Enstitüsü, Kütahya.(https://tez.yok.gov.tr/UlusalTezMerkezi/TezGoster?key=CwVIqqBuz1 VkysVpueogA WbDmcuntAsEsw7EBdnV273mZ9 Yt-25yZat dzPf9R3 )

Panaite, V. (2000). Haraçgüzarların Statüleri, XV ve XVII. Yüzyıllarda Eflak, Boğdan ve Transilvanyalılar Üzerine Bir Çalışma. Osmanlı Ansiklopedisi içinde (c.1, ss. 373-383) Ankara: Yeni Türkiye.

Papp, S. (2002). Eflak Ve Boğdan Ahidnameleri Üzerine Bir İnceleme: Osmanlı İmparatorluğu'nun Kuzeybatı Hududundaki Hıristiyan Vassal Devletler. Türkler Ansiklopedisi içinde, (c. 10, ss. 744-753). Ankara: Yeni Türkiye. Peçevi İ. E. (1982). Peçevi Tarihi II. Bekir Sitkı Baykal (Çev.). Ankara: Kültür ve Turizm Bak. Sözen, Z. (2002). Osmanlı Kültürünün Eflak 
Ve Boğdan'ın Yaşamına Etkisi. Türkler Ansiklopedisi içinde (c. 12, ss. 15-22). Ankara: Yeni Türkiye.

Uzunçarş11ı, İ. H. Onaltıncı Yüzyılın Ortalarında İslamiyet'i Kabul Etmiş Olan Bir Boğdan Voyvodas1. Belleten, S. 69, ss. 83-87.

Uzunçarş11, İ. H. (1994). Osmanlı Tarihi, III. Ankara: Türk Tarih Kurumu.

Yüksel, A. (2013). II. Mahmud Devrinde Osmanlı İstihbaratı. İstanbul: Kitap.

Yüksel, A. (2014). Rusların Kafkasya’yı İstilası ve Osmanlı İstihbarat Ağı, İstanbul: Dergâh.

Yüksel, A. (2017). Teşkilat-1 Mahsusa'ya Kadar Osmanlı İmparatorluğu'nda İstihbaratın Mali

Boyutu. Zafer Gölen-İbrahim Serbestoğlu (Ed.), New Trends In Social And Liberal Sciences-2 (s.593-622). Ankara: Gece. 